\title{
Prakrit in the Language Order of India
}

What historical a priori provided the starting-point from which it was possible to define the great checkerboard of distinct identities established against the confused, undefined, faceless, and, as it were, indifferent background of differences?

- MICHEL FOUCAULT, THE ORDER OF THINGS ${ }^{1}$

"It should be understood that the people of India have a number of languages," Mīrzā Khān observes in his Gift from India in 1676, "but those in which books and poetical works may be composed-such as would be agreeable to those who possess a refined disposition and straight understanding-are of three kinds." ${ }^{2}$

With these words, addressed to the son of the Mughal emperor Aurangzeb, Mīrzā Khān articulated the age-old schema of the bhāsātraya, the "three languages." This was one of the most enduring ways of representing language in India. Of course, then as now, India was one of the most linguistically diverse places on earth. But the sense that Mīrzā Khān assigns to the schema of three languages is that these three alone answer to the purposes of textuality, and especially the higher purposes of textuality to which he alludes. ${ }^{3}$ Mīrzā Khān's three languages are Sanskrit, Prakrit, and the vernacular $(b h \bar{a} k h \bar{a})$. He is simply reframing what was common knowledge in India. The three slots in the schema were not arbitrary: for nearly fifteen hundred years, they had been filled in more or less the way that Mīrzā Khān describes. ${ }^{4}$ But let's now turn to his description of Prakrit:

Second, Parākirt. This language is mostly employed in the praise of kings, ministers, and chiefs, and belongs to the world, that is to say, the world that is below the ground; they call it Pātāl-bānī, and also Nāg-bānī, that is, the language of the lowest of the low, and of reptiles of mean origin, who live underground. This language is a mixture of Sahãskirt, mentioned above, and Bhākhā, to be mentioned next. ${ }^{5}$

On originally reading this passage, I had two reactions. The first was that of my inner historian, who recognized that Mīrzā Khān's description was remote from what I knew about Prakrit-and, more important, what was known about Prakrit 
even in Mīrzā Khān's time. Nobody ever represented it as a language of the snakes, except, as I later found out, a handful of other authors from the seventeenth and eighteenth centuries. ${ }^{6}$ Given that this linguistic tradition began, as I'll argue here, around the first century, Prakrit was only known as the "language of the snakes" at the tail end of its long history. Hence I wondered what Mīrzā Khān's sources might have been. But my second reaction was to the description itself. Mīrzā Khān begins in a register of descriptive ethnography ("the people of India have a number of languages") and then transports us to a snake-infested subterranean realm. Prakrit, he tells us without a hint of contradiction, is the language of the lowest of the low and yet used to praise the highest of the high. At this point, the question of Mīrzā Khān's sources gave way to another question: what would it mean for Prakrit to be the language of the snakes anyway? It is obviously not a language in the sense of the Linguistic Survey of India: we can't send a field linguist into the underworld and have him ask the resident serpents how they say a couple dozen words. Is Mīrzā Khān simply reporting folk beliefs or myths? Does this mean that we have left the surface of the earth for good, and retreated into a fantastic realm of imaginary language? Or can we-should we-try to recover some shards of historical truth from Mīrzā Khān's account?

This passage, as Foucault famously said of Borges's Chinese encyclopedia, shatters the familiar landmarks of our thought. Not because it presents a completely new picture of language, but because it presents the utterly familiar picture of the three languages in an uncanny way. ${ }^{7}$ Instead of asking how we can accommodate Mīrzā Khān's remarks within "this world," the world of truths to be discovered by social science, we are led to ask what worlds the language practices he describes belong to. Where can we accommodate them, if not within the familiar landmarks of our thought? Among experts, the question of the "reality" of Prakrit, or Sanskrit for that matter, has been debated for more than a century: where, when, and among whom did these languages exist, and what was their mode of existence? Were they spoken or written, natural or artificial? What kinds of histories do they have, and how can they possibly be related to other kinds of histories-of spoken language, for example, or of society and politics, or of literature and the imagination?

This book addresses these questions by telling the story of the mysterious snake-language. Prakrit is not just a curio in the cabinet of India's languages. It is the key to understanding how literary languages worked in premodern India as a whole, and it provides an alternative way of thinking about language-about its modes of existence, its unity and diversity, its sociality, and its imaginative possibilities. For the way we think about language today is almost completely bound up with the nation and its histories and aspirations: this is as true in linguistics departments, where national languages provide convenient labels for collections of differences, as it is among those who espouse some form of linguistic purism 
or chauvinism. Prakrit, by contrast, is a language without a people and without a place, between and beyond Sanskrit, the "language of the gods," and the vernacular, the "language of men."

\section{LANGUAGE ORDERS}

One important starting point for my investigation is Mikhail Bakhtin's observation that "[a] unitary language is not something which is given (dan) but is always

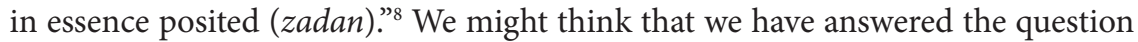
"What is Prakrit?" with a series of descriptions: what are its grammatical features, what texts are written in it, who wrote those texts, and so on. For a language as little studied as Prakrit, much of this descriptive work remains to be done. ${ }^{9}$ But Bakhtin's comment suggests that this is only the beginning. To ask "What is Prakrit?" is not just to ask what it is like, but to ask how, by whom, and for what purposes Prakrit was "posited" as a language over the course of its history.

Throughout this book I address these questions through the concept of a language order. This concept foregrounds the fact that languages interact with each other in such a way that it is impossible to characterize a language without reference to the other languages that fall within its cultural-historical horizons. It is, of course, possible to characterize a language in that way as a formal system, through the contrasts it articulates and its procedures of derivation. This was Ferdinand de Saussure's goal in delimiting "internal linguistics" from the study of all languageexternal phenomena. ${ }^{10}$ Saussure's success in defining the object of linguistics as a formal system, however, has meant that comparatively little attention has been paid to the ways in which languages are posited in relation to each other. The term "language order" refers to the way that languages are ordered within a culture, to the recurrent patterns and schemas and tropes by which they are defined and represented, the names under which they are known, and the values with which they are associated. A language order provides the linguistic parameters for all manners of cultural practices, from scratching one's name on the wall of a cave to composing a text on poetics.

India was home to one of the premodern world's most productive and dynamic textual cultures, and one of its distinctive characteristics is its use of a small number of languages that stand, almost literally, outside of space and time. The practices of stability and continuity are well known in the case of Sanskrit: some families have been memorizing and reciting the exact same Sanskrit texts, down to the smallest details of accent, for more than twenty-five hundred years. But they apply mutatis mutandis to Prakrit as well. The Prakrit that Rāma Pānivāda wrote in eighteenth-century Kerala was self-consciously identical to the Prakrit that Rājaśekhara wrote in tenth-century Kannauj, which was in turn self-consciously identical to the Prakrit that Hāla wrote in first- or second-century Maharashtra. 
These are, of course, limit cases, but premodern India was exceptional in the stability of its textual languages, and thus it is an important site for thinking about how languages are posited as unitary over the course of their history.

Another characteristic of the textual culture of premodern India, which is less well known today but was certainly taken for granted and occasionally remarked upon by premodern Indians themselves, is the deep and systematic interrelation between textual languages, not just on the level of their linguistic form but on the level of the practices, discourses, and imaginative worlds that they co-constitute. Even languages that modern linguistics has taught us to think of as genetically distinct, such as Sanskrit and Kannada, were situated by the people who wrote in them within a continuous, if capacious, frame of conceptualization and analysis. This frame anticipates in certain respects the twentieth-century concept of the "linguistic area."

Language, in short, was ordered in premodern India in a way that seems to have few parallels, premodern or modern. That is why, necessary though it is to describe and account for this order, it seems preferable at this stage of research to simply state it as a fact, and to allow its features to emerge over the course of this book. At the foundation of this language order was a dichotomy between Sanskrit and Prakrit. Built upon this "schema of co-figuration," as I have learned to call it from Naoki Sakai, are a range of other schemas: the three languages, such as we encountered above in Mìrzā Khān; the three and a half languages; the four languages; the six languages. Amid this apparent arithmetic confusion-which I discuss in detail in chapter 5 -it is important not to lose sight of the fact that all of these schemas situate languages in complex relations with each other, and differentially assign them over the entire field of textual production.

Such a structure is certainly not hidden. It is explicitly announced in some of the most influential and well-read works of Indian literature, such as Dandin's Mirror of Literature (ca. $700 \mathrm{CE}$ ) — "the text can be Sanskrit, Prakrit, Apabhramsha, or mixed"-and it reaches down into every letter of every text. ${ }^{12}$ Nevertheless, only a few scholars have thought critically about the language order of premodern India as a whole, especially as a condition for the emergence and articulation of particular language practices. Sudipta Kaviraj discussed the history of the "internal economy of language" in India in an attempt to account for some of the differences between the imagination of language in the domain of the political in modern India and in modern Europe. And Sheldon Pollock's theorization of Indian literary culture depended on identifying its internal structure and principles, among which is the principle of "literary language as a closed set." ${ }^{13}$

I am not claiming that this language order is absolutely unique or exceptional. What I am claiming, however, is that it is important not to assume that any particular framework that was developed in and for the modern West will completely account for the ordering of language practices in premodern India. The idea of 
a language order allows us to remain theory-neutral and prevents us from being theoretically naive. A survey of the wide range of phenomena that linguistic anthropologists have placed under the rubric of "language ideology" shows, first of all, that hardly any of this work addresses the non-modern non-West, and secondly, that much of this work attempts to reduce the organization of language to putatively more basic categories such as prestige, distinction, legitimacy, and identity. ${ }^{14}$ Whether or not this reductive maneuver is justified by the facts in a given case, the ways in which language is embedded in social and political life does need to be carefully - I would say: philologically_recovered from the facts, rather than assumed as a given. There is no default language order. ${ }^{15}$

In the exploration of what language is, and what it means, in the non-modern non-West, we must not assume, for concepts that have become thoroughly naturalized in the modern West, "a victory, or the right to a victory." This phrase betrays that my own thinking about language orders has been guided by a broadly Foucauldian perspective, especially as applied to language by Naoki Sakai. I think of language orders as "discursive spaces" in which the production of texts is "controlled and dominated by presupposed conditions" which are, however, immanent in the discursive spaces themselves and not tyrannically imposed upon them from without; the spaces accommodate "regimes of narrating, reciting, listening, writing, reading, and translating and writing," each of these a "set of protocols and rules" that determine how these actions are to be performed. ${ }^{16}$

\section{PRAKRIT AS A CLASSICAL LANGUAGE}

This book presents Prakrit as a critical component of a complex of cultural practices that have to do with language. These language practices, as I call them, are centered on the domain of literature, since it is largely in and through and for literature that languages like Prakrit are cultivated, but they extend far beyond it. It is convenient and appropriate to call this complex of language practices "classical," since they form part of what people generally recognize as classical Indian culture.

It is difficult to define the classical with precision in any cultural context, but one signal characteristic of classical Indian culture is the use of Sanskrit as the preeminent language of political and literary expression. Even on this criterion, the temporal, geographic, and social boundaries of classical culture are still very fuzzy. But this fuzziness allows us to imagine a "core domain" of classical culture found in educated and often elite circles of South Asia throughout the first millennium CE, which largely coincides with what Sheldon Pollock has theorized as the "Sanskrit cosmopolis," alongside a number of other domains. ${ }^{17}$ Hence "classical" easily applies to practices of the court of Harșa of Kannauj in the seventh century: this king, the subject of a famous historical poem in Sanskrit by Banna, was the author of several Sanskrit plays based on older story-cycles. But it also applies to the practices 
of Buddhist monasteries of the Tarim basin of the middle of the first millennium, where monks translated Buddhist literature in Sanskrit into Khotanese and Tocharian, or of the courts of eastern Java in the early second millennium, where poets reimagined the great works of Sanskrit literature. Hans-Georg Gadamer's definition of the classical, as a "notable mode of being historical, the historical process of preservation that, through constantly proving itself, allows something true to come into being," evokes several features that apply to the cultural complex under discussion here: its historicality, its monumentality and exemplarity, its interpenetration with political, ethical, and aesthetic ideals. ${ }^{18}$

When I call Prakrit "critical," I mean, first, that it was one of the main languages of classical Indian culture, and second, that understanding Prakrit is crucial for understanding the language order of classical India. I will explain the first point in this section, and the second in what follows.

To get a first impression of what Prakrit was in this context, we can ask one of classical India's most remarkable intellectuals, who also happened to be one of its most famous kings: the Pāramāra overlord Bhoja, who ruled from Dhārā, in what is now Madhya Pradesh, in the first half of the eleventh century. Bhoja produced, or at least had a hand in producing, important works in Sanskrit on the topics of Yoga, architecture, Tantric Shaivism, grammar, and literary theory. In one of his works of literary theory, Necklace of Sarasvatī he listed Prakrit as one of a handful of languages in which literature can be composed. As an example, he cited the following verse:

tujjha ṇa jāṇe hiaaṃ maha uṇa maaṇo divā va rattiṃ va

nigghiṇa tavaï balịnạ̣ tui juttamanorahāi aṃgāiṃ

I do not know your heart.

But as for me, cruel one,

love torments my body, wracked with longing for you,

ever more severely

day and night. ${ }^{19}$

This verse comes from Kālidāsa's Recognition of Śakuntalā, composed around the beginning of the fifth century CE, a classic of Indian literature if ever there was one. At this point in the play, King Duśyanta has married the heroine, Śakuntalā, and returned home-soon to forget about his new bride altogether as a result of a curse-while Śakuntalā remains at the hermitage where she was raised. Grieved by separation, she is advised by her friends to send a message to the king. And the message is the verse quoted above.

Bhoja was writing about a thousand years into the history of Prakrit as a literary language. By this time there were dozens, if not hundreds, of texts he could have chosen. But he picked this verse because it supports his point that the principle of suitability (aucitya) informs the choice to employ one type of language (jāti) over 
another. What kind of suitability might Bhoja have had in view? For one thing, Recognition of Śakuntala is a stage play, and one convention of the genre is that different characters speak different languages based on their gender and social status. Male characters of a high status typically speak Sanskrit, while male characters of a lower status, and most female characters, speak Prakrit. If you know only one thing about Prakrit, this is likely to be it: that Prakrit serves to represent the speech of characters who do not speak Sanskrit, that it is the language conventionally assigned to women, children, low-lives, and the uneducated. Thus Prakrit's association with "the lowest of the low" according to Mīrzā Khān. The verse Bhoja quotes is suitable in the very superficial sense that it adheres to the generic conventions of the play.

Despite the fact that Prakrit is now generally associated with these snippets of dialogue in Sanskrit stage plays, Prakrit was also used as the primary language of other types of texts-single-verse lyrics, longer narrative poems, historical poems, and romances. Prakrit was, in other words, the language of Prakrit literature. And that literary tradition, by most accounts, began with an influential anthology of single-verse poems, compiled by Hāla around the first or second century, called Seven Centuries. Thanks in part to this text, the Prakrit language had a long-lasting association with the inward-looking themes of erotic lyric. ${ }^{20}$ Bhoja quoted the verse from the Recognition because in it Śakuntalā expresses her love for Duśyanta in a type of language that is eminently "suitable" for this purpose. Everything about this verse-its language, its meter, its theme of love-in-separation, its meta-literary character (it is composed as a message), and its studied earnestness-evokes the rich world of Prakrit poetry beyond the world of Kālidāsa's play.

Prakrit was not just a part of the classical Indian world. Prakrit texts were themselves classics. They continued to be read and studied, in some cases more than a thousand years after they were composed. Among theorists of literature in India, they represented more clearly than almost any other texts literature's affective and suggestive powers. As most students of Sanskrit literature know, the ninth-century theorist Ānandavardhana elaborated his revolutionary concept of "suggestion" by citing Prakrit verses. Many of these verses are taken from the Seven Centuries of Hāla, but some are taken from the now-lost God of Five Arrows at Play, a Prakrit poem that Ānandavardhana himself composed in order to illustrate aspects of his poetic theory. Ānanda develops his argument in his Light on Suggestion by first producing a reading of the following verse from Seven Centuries:

bhama dhammia vīsattho so suṇao ajja mārio teṇa golāaḍa-viaḍa-kuḍumga-vāsiṇā daria-sīheṇa

Go your rounds freely, gentle monk, the little dog is gone.

Just today from the thickets by the Godā came a fearsome lion and killed him. ${ }^{21}$ 
Ānanda cited this verse for the simple reason that what is "suggested," namely, that the monk should fear for his life, is the opposite of what is actually stated, namely, that the monk should go about his business without a care. Readers knew, in accordance with long-standing conventions for reading Prakrit poetry, that the speaker was a woman trying to get a flower-picking monk away from the place where she had arranged to meet her lover. This verse would continue to be discussed for centuries after Ānandavardhana by those seeking to refute or reinforce his theories, especially among the intellectuals of Kashmir. Bhaț̣a Nāyaka, for example, added that the words "gentle monk" and "fearsome lion" are what allow the suggested meaning to get off the ground, and Mahimabhatta attempted to reduce the suggestion in this verse to a case of garden-variety inferential reasoning. Abhinavagupta and Mammața defended Ānandavardhana’s interpretation. ${ }^{22}$

The lyrics of the Seven Centuries helped to establish Prakrit as a literary language in the early centuries of the common era. In fact, they helped to establish the category of "literary language" itself. Over the next several centuries, Prakrit texts such as Hari’s Victory and Rāvana’s Demise, by the Vākātaka kings Sarvasena (late fourth century) and Pravarasena II (early fifth century) respectively, would become models for the courtly epic, rich in description and poetic tours de force. Meanwhile, Prakrit was the preferred language, for much of the first millennium, for the fictional romance. One of the earliest examples of this genre is Pālitta's Tarangavati , probably composed in the first or second century. Subsequent romances include the Haribhadra's Story of Samarāditya, Uddyotana's Kuvalayamālā, and Kautūhala's Lìlāvatī, all from around the eighth century. Throughout this period, Prakrit continued to be used in plays, in the dual functions noted above: to represent the speech of certain kinds of characters, and to introduce elements of lyric and song.

As a language of systematic knowledge, Prakrit's scope was more limited. But in light of Sanskrit's near-total dominance of this domain, it is remarkable that Prakrit was used at all. We notice, first of all, that Prakrit was employed as the language of systematic knowledge about Prakrit literature: in grammar and lexicography, in metrics, and in the analysis of figures of speech. Although Sanskrit eventually supplanted Prakrit in most of these discourses, they slightly complicate the story of Sanskrit as the exclusive language through which literary culture theorized itself. There are, besides, Prakrit texts on a range of "practical" subjects, ranging from alchemy and medicine to divination and gemology. One example is Hara's Belt by the tenth-century author Mādhuka, a wide-ranging compendium of procedures (yogamālā), such as casting love spells or treating snakebites. These texts slightly complicate the story of Prakrit as an exclusively literary language. ${ }^{23}$

Besides being used for literary and scientific texts, Prakrit was used for religious purposes, above all by the Jains. Jainism is a religion based on the teachings 
of Mahāvīra, an earlier contemporary of the Buddha, that teaches asceticism and restraint as the means of obtaining liberation from the cycle of transmigration. ${ }^{24}$ It is largely as a Jain language that Prakrit is studied today. The boundaries between these three categories-literary, scientific, and religious-are fuzzy, but we can point to a number of key genres in this last category. One is the profusion of commentary on Jain canonical literature, unfolding through several layers (niryuktis, bhāşyas, cūrṇis, and țikās). It was probably in this domain that Prakrit was first employed as a textual language. Other genres include stories meant to inculcate Jain virtues, stories about important Jain figures, legendary and historical, hymns to the founders of the religion, and systematic expositions of Jain doctrine. Prakrit may be indispensable for studying Jainism, but Prakrit is hardly the only language that Jains used, nor did only the Jains use Prakrit for religious purposes. There are, for example, Shaiva tantras and Vaishnava devotional poems in Prakrit as well. ${ }^{25}$

Beyond being cultivated by members of disparate religious traditions, Prakrit was the language of a literature in which religious differences disappeared. It was, as Rājaśekhara and Bhoja said of literature more generally, common to all religious traditions. ${ }^{26}$ No genre represented this better than the anthology or "treasury" (kośa). Prakrit anthologies were produced by Hindus, Buddhists, and Jains, and it is only a slight exaggeration to say that we would not be able to identify the religious identity of their authors but for the invocations and colophons. It is no exaggeration at all in the case of the author of a thirteenth-century Message Poem (Sandeśarāsaka), who calls himself "the lotus of his family in Prakrit poetry": only his hint that his family comes from "the land of the Muslims" allows us to decode the Prakrit name he gives us, Addahamāṇa, as 'Abd ur-Raḥmān. ${ }^{27}$

Participants in the literary culture of India viewed Prakrit literature as an "inexhaustible treasury" that they held in common: after an initial investment by classical authors of the early first millennium, its resources-themes, figures, turns of phrase, even whole verses-were continually drawn down and replenished by poets, anthologists, and literary theorists. For example, the Jain monk Jineśvara included in his Treasury of Gäthā-Jewels (1194 CE) verses that had been circulating, in and outside of such anthologies, for nearly a thousand years. Jineśvara had no hesitation whatsoever about including verses in praise of Viṣnu and Siva in his collection. ${ }^{28}$

To summarize, Prakrit was a classical language in a number of overlapping senses. Prakrit texts were considered "classics" and studied for upwards of a thousand years, beginning in the first couple of centuries of the common era. Knowledge of the language and the literature was a key component of cultural fluency. Prakrit was cultivated across a vast swath of southern Asia, from Kashmir to Tamil Nadu, and from Sindh to Bengal, and it was at least known, if not studied, in Cambodia and Java as well. ${ }^{29}$ Like Sanskrit, it was a language 
of literary intellectual culture, and cut across regions and religious traditions. If it was not cultivated as intensively or as broadly as Sanskrit was, it was nevertheless cultivated by those at the very apex of cosmopolitan culture, such as Bhoja and Ānandavardhana.

Yet Prakrit has unquestionably fallen from its earlier glory. To describe the state of Prakrit today, we might paraphrase what a medieval Jain monk said about one of the classics of Prakrit literature, Taranigavatī by Pālitta: nobody recites it, nobody asks for it to be recited, nobody talks about it; it has become the exclusive preserve of scholars; nobody else can do anything with it. ${ }^{30}$ If people think of Prakrit at all, they generally think of it as a mild deformation of Sanskrit used exclusively in plays. And even the Prakrit portions of plays are always read in the Sanskrit translations, called "shadows" (chāyās), that are always printed alongside them, or sometimes even instead of them. In circumstances like these, the complex intertextuality of the verse from the Recognition of Sakuntala mentioned above will inevitably fall flat. But Kālidāsa is lucky to have his texts read at all in the twenty-first century. The same cannot be said of Pālitta, whose Tarangavati is lost, or Vairocana, whose Brilliance of the Connoisseurs remains unpublished. Even Rāvana's Demise by Pravarasena struggles to find readers today, despite the fact that the Mughal emperor Akbar personally requested that this classic text be explained at his court. ${ }^{31}$ Only a few Prakrit texts survive; of those that survive, not all have been published; and of those that have been published, few have attracted any kind of critical scholarship. What accounts for this neglect?

Prakrit is even more vulnerable than other classical languages to the various processes by which modernity dismisses, discounts, marginalizes, and fetishizes the non-modern. Take, for example, the official designation of "classical language" that the Government of India has, since 2003, bestowed upon Tamil, Sanskrit, Kannada, Telugu, Malayalam, and Odia. Prakrit is missing from this list and likely will remain missing for some time, despite the fact that it has a longer history of attestation than all of them, except for Sanskrit and possibly Tamil.

One reason for its absence is that it does not stand for a regional, national, ethnic, or even a religious identity that might serve as a bulwark against being forgotten. Prakrit texts are "homeless texts"; no one claims to own them and they figure in no one's cultural politics. ${ }^{32}$ A handful of attempts to make Prakrit a more important component of Jain religious education are exceptions that prove the rule. ${ }^{33}$ Another reason is that Prakrit is so deeply embedded in Sanskrit culture. It is widely seen as a dialect of Sanskrit, with the implication that it fails to be a language in the full sense of the word. Sanskrit has always cast its shadow-its chāy $\bar{a}$-over Prakrit. Of all of the literary languages of South Asia, Prakrit alone was close enough to Sanskrit-both linguistically, in terms of their forms, and discursively, in terms of their co-occurrence in texts-to be read as Sanskrit. When we read a Sanskrit "shadow" of a Prakrit verse in modern editions, we are following a 
practice that was already in place in the tenth century, when Abhinavagupta translated every Prakrit verse he encountered in Ānandavardhana's Light on Suggestion into Sanskrit. Hence Prakrit was very rarely conceived of as a language unto itself, with its own distinctive practices and its own history.

\section{DEFINING “PRAKRIT”}

Before discussing the stakes of Prakrit's history, I must be very clear about what I mean, and don't mean, by the word "Prakrit." Over its history, this word has had a wider range of application than any other language name I can think of, and a productive discussion of Prakrit's history requires that we limit this range somewhat. In this section I discuss the scope of the term "Prakrit," its singularity or plurality, and the term "Mahārāșțrî̀," which has often been used as a synonym or near-synonym of Prakrit. This section will also double as a précis of the history of scholarship on Prakrit, since that narrative shows how the signification of "Prakrit" has shifted according to the priorities of scholarship.

William Jones's 1789 translation of the Recognition of Śakuntalā is often credited with introducing classical Sanskrit literature to the Western world. In doing so, it also introduced Prakrit, as the title page proclaims: "translated from the original Sanskrit and Prakrit." ${ }^{34}$ Very soon afterwards, based exclusively on the evidence of the plays, "Prakrit" was understood as a vernacular language in contrast to Sanskrit, although there was considerable debate over whether it was a "real" or "fabricated" vernacular. In 1837, Christian Lassen, in his Institutiones Linguae Pracriticae, provided a systematic survey of Prakrit and its varieties following their description in Indian sources. He introduced Western audiences to premodern grammars of Prakrit, including the Light on Prakrit by Vararuci. Lassen drew attention to the ambiguity of the term "Prakrit": on the one hand, it referred to a group of closely related literary languages; on the other hand, it referred to one of these languages in particular-Prakrit par excellence (Pracritica $\left.\kappa a \tau^{\prime} \dot{\varepsilon} \xi o x \eta े v\right)$-which alone was used as the primary language of entire poems. ${ }^{35}$ It was not until the later nineteenth century that scholarly editions of these poems were brought out. Siegfried Goldschmidt edited Rāvana's Demise in 1880, and Albrecht Weber edited Seven Centuries in $1881 .^{36}$ These works, which remain unsurpassed to this day, gave a clear picture for the first time of the second, more specific, sense of Prakrit. Around the same time, Richard Pischel undertook the study of premodern Prakrit grammars, in the course of which he edited two important works of the twelfth-century polymath Hemacandra, the Garland of Regional Words and the Prakrit section of his grammar (Siddhahemacandra). Georg Bühler aided the effort by editing another Prakrit lexicon, the Prakrit Lakșmī of Dhanapāla. By 1900, Pischel had finished his magisterial grammar of Prakrit in all of its varieties, A Grammar of the Prākrit Languages. ${ }^{37}$ Meanwhile, Weber's student Hermann Jacobi brought to light the vast 
literature of the Jains, much of which was written in Prakrit and closely related languages, and accompanied his editions, translations, and primers of this material with shorter linguistic and philological studies..$^{38}$ In this effort he was joined by Jain scholars in India, including Punyavijaya Muni and Jinavijaya Muni, who led an effort to publish the Prakrit texts found throughout the manuscript libraries of India. This effort continued throughout the twentieth century, and included A. N. Upadhye and H.C. Bhayani, to whom we are indebted for many fine editions. ${ }^{39}$

Jacobi represented a transition between two ways of conceiving and naming Prakrit. We can see this most clearly in his Ausgewählte Erzählungen in Mâhârâshtrî̀, which was instrumental in introducing the language to the wider scholarly public. There he divided the "Indic languages," a family related by descent from a common ancestor, into three stages of development: Old Indic or Sanskrit, Middle Indic or Prakrit, and New Indic or Bhāșā. The three-stage model is still generally accepted by linguists and philologists..$^{\circ}$

Each stage has two names, which reflects Jacobi's commitment to the perspectives of what I call below a "natural" and "cultural" history of language. "Old Indic," "Middle Indic," and "New Indic" are "etic" names that nobody who used these languages would have recognized; they represent the natural historian's attempt to classify these languages along a single developmental continuum. "Sanskrit," "Prakrit," and "Bhāṣā" are "emic" names. They represent the languages that were picked out, named, and used for literary purposes. And they coincide exactly with the three languages that Mīrzā Khān identified. Later in his career, Jacobi would use "Prakrit" when writing in a literary-historical mode and "Middle Indic" when writing in a linguistic mode.

Jacobi's well-intentioned parallelism has given rise to a number of misunderstandings. One is that the etic and emic terms are synonymous. They aren't. "Middle Indic" and "Prakrit" are not just the modern and premodern ways of picking out the same languages, or even the same kinds of languages. What underwrites this false equivalence is the idea that any language that deviates from Sanskrit in any way is and always was Prakrit. I will call this a "broad" definition of Prakrit. There is some warrant for this idea within the Indian tradition, but one major problem with it is that it empties the categories of "Sanskrit" and "Prakrit" themselves of any concrete referentiality and employs them as transhistorical categories of language-refined versus unrefined, artificial versus natural-despite the fact that the processes that give meaning to these categories are, of course, historical..$^{41}$ Another misunderstanding is that Sanskrit, Prakrit, and Bhāṣā somehow follow each other in history. Jacobi was careful to avoid this suggestion by referring to stages of development (Entwicklungsstufen) rather than stages of attestation. Indeed, against the general expectation that linguistically "later" forms of a language are historically attested "later" as well, the entire linguistic history of India provides many striking counterexamples, including one that Louis Renou identified 
as the "great linguistic paradox of India": Middle Indic languages are attested in the inscriptional record centuries before Old Indic languages are..$^{42}$ Yet when we think of India's language practices as comprising a "simultaneous order," situations like this become less paradoxical, and we can more readily countenance a work like the eighth-century Kuvalayamālā: written largely in Prakrit ("Middle Indic"), with a sprinkling of Sanskrit verses ("Old Indic") and a few snippets of vernacular conversation ("New Indic").43

The broad definition is typically adopted by scholars concerned with the natural history of language: given the project of tracing the genealogical relationship between the ancient, medieval, and modern languages of India, a sufficiently broad term is needed to encompass all of the forms of speech that might figure in this genealogy ${ }^{44}$ Hence "Prakrit" becomes a cover term for languages that were never called Prakrit in ancient India: the languages of Ashoka's inscriptions; the languages of later inscriptions in India ("Monumental Prakrit," "Lena Prakrit," or "Stūpa Dialect") as well as in Sri Lanka ("Sinhalese Prakrit"); the language of the Theravāda Buddhist canon, now commonly known as Pali; the popular Sanskrit of Buddhist literature in the early centuries CE ("Buddhist Hybrid Sanskrit"); the language of birch-bark scrolls from northwestern India to Western China ("Gandhari Prakrit" and "Niya Prakrit," both generally called "Gandhari" these days); essentially, any piece of the linguistic puzzle between the Vedas and the appearance of the modern vernaculars, which is to say, the entire linguistic puzzle. ${ }^{45}$ There are some good reasons for grouping these enormously diverse languages under the heading of "Middle Indic"; I am less sure that they should be grouped under the heading of "Prakrit."

For some scholars, including Richard Pischel and Oskar von Hinüber, "Prakrit" is a subset of "Middle Indic." It refers specifically to a set of literary languages, and Pischel took care to point out that this latter term did not simply mean "languages that happen to be used in literature," but rather "languages that are used exclusively in literature." 46 This narrow sense of "Prakrit" includes two distinct groups of languages. One is the "scenic Prakrits," which are used exclusively in plays. They are given names which suggest that they are related to particular regions-Śaurasenī, Māgadhī, Āvantī, and so on-although these regional associations are almost totally notional. These are secondary languages, to use Sheldon Pollock's term, in that they are never used as the primary language of a literary text. ${ }^{47}$ They are also considered to be Prakrits only in a secondary sense, at least according to the earliest theorists..$^{8}$ The other group includes primary languages, and above all the language of literary classics like the Seven Centuries. As Dandin said in his Mirror of Literature, "people know that Prakrit par excellence is the language based in Mahārāștra, in which poems such as the Building of the Bridge (i.e., Ràvana's Demise), an ocean filled with the jewels of good poetry, have been composed.49" As Dandinin's description suggests, this language too has an association 
with a particular region, namely, Mahārāșțra, and for this reason it is often called Mahārāșțrī. But we should not be misled into thinking that Mahārāșțī bears the same relation to Mahārāșțra as the scenic Prakrits bear to the regions for which they are named. They are distinct language practices, with distinct histories and distinct connotations of the regional.

The narrow sense of Prakrit maps closely onto what premodern Indians meant by the word. And one of my contentions is that if we want to understand what Prakrit was, we need to start from what the people who actually used this word meant by it. The appearance of "Prakrit" as a language name and the literature it designates marks a major turning-point in the cultural history of language in India-a turning-point that is completely obscured if we continue to equate "Prakrit" with "Middle Indic." Moreover, "Prakrit" designated a language that had a stable identity, such that it was equally possible to compose Prakrit texts in the eighteenth century as in the first, and it therefore cuts clean across the linguistic periodization implied by "Middle Indic." ${ }^{\circ}$ Prakrit, put simply, is what Prakrit texts tell us they are written in: when Seven Centuries proclaims that it is "Prakrit poetry" (pāua-kavvaṃ), when Tarañgalolā, Lìlāvaī or Kuvalayamālā proclaims that they are in the Prakrit language ( $p \bar{a} a a, p \bar{a} a \bar{a} e$ bhāsāe, pāiya-bhāsā-raiyā), or when Vajjälagga includes a whole section on the beauty of Prakrit poetry, we know what they are referring to, and it's not a stage in the historical development of a family of languages. ".1 "Prakrit poetry," says a verse in Brilliance of the Connoisseurs, "is like a beautiful courtesan: erotic, alluring, full of rasa, delicate, provoking excitement and desire, it captivates your heart." ${ }_{52}$ The name of Prakrit was retroactively applied to the language of Jain scripture, and on occasion to the language of Buddhist scripture as well, but the historically and conceptually primary sense of the word remained the language of literary texts composed in the first half of the first millennium CE. Indeed, against those who argued that Buddhist scripture could be authoritative despite being composed and transmitted in Prakrit, the seventh-century philosopher Kumārila Bhatța claimed that the language was "not even Prakrit." 53

\section{UNLOCKING THE LANGUAGE ORDER}

If Prakrit is indeed a "minor" language in a certain sense-whether that means being a subordinate part of a language order dominated by Sanskrit, or constituting a minority of textual production in premodern India-it is nevertheless a grave mistake to equate "minor" with "unimportant": "there is nothing that is major or revolutionary," Deleuze and Guattari assert, "except the minor." ${ }^{54}$ Prakrit gives us an opportunity to reconceptualize and rehistoricize the language order of premodern India. It is the most important Indian language you've never heard of. 
What we think of as the literature of classical India-its genres, its styles, its figuration, its tropes, and most of all the languages in which it was composed-exists within a framework that Prakrit texts played a crucial role in establishing. One of the organizing features of this framework was the contrast between Sanskrit and Prakrit, which gave each its name: samskrta means "refined," and prākrta "common." ${ }_{55}$ This dichotomy came to inhere in the concept of language itself: to write a text in classical India meant to write it not just in language, but in a language. Any system of signs could be language, but only a well-defined cultural practicedefined, that is, by the exhaustive dichotomy of Sanskrit and Prakrit-could be $a$ language. To simplify the picture slightly, prior to the first and second centuries $\mathrm{CE}$, the limited evidence that coins and inscriptions make available to us presents a continuum of languages, but we have very little evidence for the names of these languages, or how people otherwise distinguished them. But after the second century, in order to count as a text at all, a text had to be written in one of a small set of languages that were named and defined in relation to each other, and by far the most important of these languages were Sanskrit and Prakrit.

Prakrit was a very different kind of language than Sanskrit, however. Prakrit was essentially "in-between": neither Sanskrit, the preferred language of learned discourse, nor a regional vernacular; this is why the threefold schema, such as we find it in Mīrzā Khān, is so often invoked. It was also ambiguous, being at once the language of a sophisticated and courtly literature and the language used to mimetically represent the speech of the unsophisticated and uncourtly, as Mīrzā Khān also suggests. For these very reasons it was, and remains, important for thinking about the tensions inherent in textual language practices: between the ideal of a transregional discourse and the ineluctable imprint of the regional; between the discursive figure of the author and the social figure of the speaker; between being circulated and being read, spoken, and understood.

The significance of Prakrit lies, further, in its role in the major historical articulations of language orders in India: specifically, the formation of the "Sanskrit cosmopolis" around the second century CE, and the process of vernacularization that began, or at least began in earnest, around the ninth century.56 One of the foundations of the Sanskrit cosmopolis is the literature, called kāvya, through which its political, ethical, and aesthetic ideals were articulated and by which they spread. Prakrit's role in the development of this literature has been vastly underestimated. Scholars have largely looked for its origins in Sanskrit alone, either tracing its genealogy back to texts of Vedic Sanskrit, or positing a dramatic repurposing of Sanskrit from the liturgical to the expressive. Sometimes they have reached back into the Pali texts of the Buddhist canon. ${ }^{57}$ I will take up an old but mostly forgotten suggestion that kâvya began as kavva, and that Sanskrit learned to be poetic from Prakrit..$^{8}$ My argument turns not so much on the chronological priority of Prakrit literature to Sanskrit literature, which remains doubtful in any case, but on 
the clear evidence that the constitutive features of kāvya/kavva in its earliest stages easily and frequently crossed the boundaries between these languages, and indeed other languages, such as Tamil.

Prakrit is similarly underappreciated as a catalyst of, and model for, vernacularization, the process by which vernacular languages come to be used for "books and poetical works" (to use a phrase of Mīrzā Khān's). I argue that Prakrit provided the regional vernaculars with the concepts with which to theorize themselves, including the concept of the regional itself (deśya or desí). As profound as the differences are between Prakrit and the vernaculars in terms of the cultural work that each performed, it was often the case that the vernaculars were able to do this work at all only because of the example of Prakrit. Further, we can distinguish between two groups of languages that followed very different trajectories of vernacularization based on their relationship to Prakrit. Southern languages like Kannada and Telugu represented themselves in place of Prakrit in the framework that they took over from Prakrit grammar. ${ }^{59}$ Northern languages, by contrast, represented themselves as largely continuous with Apabhramsha, a language that was in turn largely continuous with Prakrit (I consider it an "iteration" of Prakrit in chapter 5). So long as they could be accommodated into these older categories, newer categories more specific than simply "language" (bhāsana were rarely devised, and in stark contrast to the South, grammars-which depend upon and rearticulate such categorial distinctions-were never written.

\section{NEW MODALITIES OF LANGUAGE}

This book is not an attempt to translate the concepts and practices of language prevalent in premodern India into the terms in which we in the twenty-first century have grown accustomed to speaking of them. I offer a biography of Prakrit in part as a critique of some of the ways of thinking about language that are available to us, both within academic disciplines and beyond them into our own "vernaculars." We have many ready-made categories that are reflected in the adjectives that we frequently put before the word "language": literary, spoken, natural, artificial, vulgar, refined, technical, vernacular, cosmopolitan, national, prestige, elite, courtly, religious, and so on. But Prakrit stubbornly refuses to fit in most of them, or it fits into categories that we imagine to be mutually exclusive: the debate over its "artificiality, discussed below, is a case in point. This intractability suggests that the major traditions of modern thought about language don't provide sufficient resources to theorize what Prakrit was. And this doubt naturally leads us to wonder whether the same traditions come up short when it comes to other languages-even the ones with which they are most closely concerned.

Let me be clear about what those major traditions of modern thought about language are. The history and structure of language are the domain of linguistics. 
The variation of language across social differentials is the province of sociolinguistics. Cultural attitudes about language are studied by linguistic anthropology. Literary history is probably most concerned with the use of language in literary texts, or what I will be calling textual language practices, and once upon a time, philology had similar concerns. All of these traditions share an ontology of language that is basically historicist (language is a thing that exists in, and inevitably changes over the course of, history) and that awards primacy to speech instead of writing (speech is a first-order, and writing a second-order, system of signs). There have been searching critiques of this ontology, but no serious alternatives have been offered. ${ }^{60}$ Most problematically, although we have a descriptive notion of literary language - the kinds of language that are used in literary texts-this ontology leaves no space for a theory of literary language. ${ }^{61}$ There is language itself and its use in a literary text. The theory of the former is linguistics; the theory of the latter is rhetoric or stylistics. But what if there was no "language itself" apart from its use in a literary text?

Prakrit in particular, and the language order of premodern India in general, represents a challenge to these widespread assumptions. Whatever spoken language it might have been "based on," and whatever this might mean, the practices of Prakrit for over a thousand years were literary practices. It cannot be reduced to a "vernacular" in the usual sense of the word, that is, a language of everyday communication. ${ }^{62}$ Let's provisionally adopt the model of social-scientific approaches to language, in which features of language practices are a "dependent variables" that need to be reduced to and thereby explained by an "independent variable." In the case of Prakrit, what could these independent variables be? It was never a national language, and never possessed the kind of extension and boundaries that such languages are supposed to have. Nor was it the language of state administration, nor was it ever controlled by state institutions. It was never anyone's "mother tongue," and nobody ever thought of it as such; certainly nobody burned themselves in the street, or fasted to death, for Prakrit. ${ }^{63}$ It was never the language of intersectarian dialogue, and only rarely that of learned discussion. It was a scriptural language only for a small minority-and even for them it was not the only such language.

How did it come to pass that in such a language, minor or not, literature would be written and studied by people of all religious persuasions throughout all of South Asia for a period of more than fifteen hundred years? Or, more important, how could this come to pass? How must a culture think of language, how must it organize it and determine it and articulate it in systematic knowledge, in order to do such things with it? Clearly, a theory of this kind of literary language would not merely treat it as a "modification" of spoken language for literary purposes, as it is usually conceived of, but as a language that does not stand in need of spoken language at all, either for its being or for its being known, and as a language that 
properly belongs to a literary culture, rather than to a community of speakers defined on social, religious, or political lines.

\section{NATURAL AND CULTURAL HISTORIES OF LANGUAGE}

I have often been asked whether I was studying Prakrit as a language or as a literature, and from my remarks above, it will be clear that I refuse the alternatives. In order to ask questions about the Prakrit language, one must first know what the Prakrit language is, where it is, how it is; one must know what it means for Prakrit to be a language. And in order to ask questions about Prakrit literature, one must know what this thing called "Prakrit" that qualifies and unifies it actually is. To see just how closely the linguistic and the literary are connected, we can consider two problems that have attended the study of Prakrit since its very beginning.

The first problem is whether the Prakrit text transmitted in the manuscripts available to us accurately represents the text that the author himself wrote. Should the transmitted text be emended on the basis of our knowledge of what Prakrit is "supposed" to look like? Or-given that this knowledge is necessarily derived from other texts transmitted in manuscript form-is the impulse to emend circular and hubristic?

Although the problem of circularity is familiar from other manuscript cultures, one thing that was never in dispute in regard to Prakrit is that the transmitted texts range from inaccurate to incomprehensible. Knowledge of Prakrit was evidently far more difficult for scribes to come by than knowledge of Sanskrit in the period in which most of our manuscripts were produced, that is, between 1300 and 1800 , and in many cases scribes clearly had no idea what they were copying. ${ }^{64}$ Furthermore, like Sanskrit, Prakrit was written in a variety of regional scripts, and each region, and sometimes each community, had its own orthographic conventions. The eighteenth-century scholar Ghanaśyāma complained loudly about a confluence of scribal error and scholarly cluelessness in one of his commentaries: instead of reading a circular mark as a sign of nasalization, "self-styled scholars" read it as a sign of consonantal doubling, and made censorious comments on the basis of their misreading. ${ }^{65}$

The question is thus not whether to emend the texts, but how, and in particular, whether we should revise the Prakrit of the manuscripts so that it matches the descriptions found in premodern grammars. In 1894, Theodor Bloch proposed to dispense with the Prakrit grammarians entirely: he argued that they could not be trusted to correctly describe the language of texts that were written centuries before them. Mārkaṇdeya, for example, wrote in the late sixteenth century, describing a language that had been used as early as the first. Bloch was criticized by scholars such as Sten Konow, Richard Pischel, and Alfred Hillebrandt who argued-although not precisely in these terms — that the knowledge systematized 
in Prakrit grammars reflects the same knowledge that the authors of Prakrit texts actually possessed. ${ }^{66}$

The discovery of manuscripts of a number of previously unknown stage plays in Kerala at the beginning of the twentieth century put the problem into focus. Several scholars ascribed these plays to Bhāsa, an early playwright (fourth century CE or earlier) of whom no other works remain. ${ }^{67}$ Does the Prakrit of these manuscripts, which diverges in several respects from the Prakrit taught by the grammarians and from the Prakrit of other plays, represent an older stage of the language? The early presumption was that these manuscripts do indeed transmit an "archaic" variety of Prakrit, which corroborates the ascription to Bhāsa. But recent work has shown that many of the alleged archaisms of "Bhāsa's Prakrit" appear in the manuscript traditions of other plays, and especially in South Indian manuscripts. These features have generally been edited out of the other plays, however, precisely because they conflict with the statements of the Prakrit grammarians. ${ }^{68}$ The common wisdom now is to collect and report all of the possible manuscript evidence, and then to "chart a navigable course" between the manuscripts and the grammarians, although there are very few examples of what such a course would look like in practice. ${ }^{69}$

Let us suppose that we have an autograph copy of a Prakrit text, such as Rājaśekhara's Karpūramañjarī (early tenth century). Is the language in front of us Prakrit?

Not necessarily. Rājaśekhara might have made mistakes, which are only identifiable as mistakes if there is a standard external to the text against which the language of the text can be judged. In the context of our example, one such standard would be Prakrit grammar. In the late sixteenth century, the eminent Prakrit grammarian Mārkaṇdeya faulted Rājaśekhara’s Prakrit, and in 1901 Sten Konow again accused Rājaśekhara of "confusing" two dialects of Prakrit when in fact he should have had his characters speak Māhārāṣțīi in verse and Śaurasenī in prose. But how do we know that this principle, which was first enunciated by Viśvanātha in the fourteenth century, would have been known to, or even intelligible to, Rājaśekhara in the tenth? Rājaśekhara himself never distinguishes between Māhārāștrī and Śaurasenī, but instead imagines Prakrit as one language, or at least one kind of language, alongside Sanskrit, Apabhramsha, and Paishachi..$^{\circ}$

This example simply illustrates the uncertainty we enter into once we begin to consider standards of language use external to the text. The grammarians are one such standard, but really they are only a proxy for the language practices that they codify and thus enshrine as normative. These are not conversational but textual practices; the language the grammarians sought to describe was that of the earliest classics of Prakrit literature, such as Seven Centuries and Rāvana's Demise. Is this, finally, Prakrit?

Yes, I think, but this answer appears to have been fairly disappointing. On the one hand, texts such as Seven Centuries, with its sympathetic vignettes of village life, appear to offer a window onto the real language practices of real people. ${ }^{71} \mathrm{On}$ 
the other hand, they only appear to do so: they are, after all, still texts, and most of them are courtly and sophisticated texts. George Grierson, one of the most influential philologists of the early twentieth century, and the director of the Linguistic Survey of India, framed the question as follows:

Unfortunately we cannot accept this literature as illustrating the actual vernaculars
on which it was founded. To adapt them to literary purposes the writers altered them
in important particulars, omitting what they considered vulgar, reducing wild luxu-
riance to classical uniformity, and thus creating altogether artificial products suited
for that artificial literature which has ever been so popular in India. These literary
Prakrits cannot, therefore, be considered as representing the actual speech of the
people at any epoch, although they are based on it, and a veil is drawn by them be-
tween us and it which it is not always easy to lift. ${ }^{72}$

Grierson was not the first to distinguish between literary Prakrit and "real vernaculars." But his views can be taken as representative of a philological tradition that persists to this day. Essential to the Griersonian vision is that literary languages can be used as evidence for reconstructing the "real" languages that underlie them, so long as we are sensitive to the distortions that literary languages introduce. Grierson confusingly called these "real" languages Prakrits as well: "For centuries the Aryan vernacular language of India has been called Prakrit, prākrita, i.e., the natural, unartificial language, as opposed to Sanskrit, samskrita, the polished, artificial, language." 73 Prakrit, the language of our texts, thus becomes an imperfect sign for Prakrit, the language that is imagined to exist prior to it, both conceptually and historically. If this seems like a contradiction, then all we need to resolve it is time: "Originally Prākrits were the spoken languages of the people and their true vernaculars," A. M. Ghatage wrote in 1936. "In course of time they were refined and polished greatly with the help of the grammarians and they were made suitable for literary expression." 74

There may seem to be a great deal of prevarication, not to speak of Orientalism, in Grierson's conception: Prakrit is what the timeless Indians have always called their unartificial language; it is also, by a constitutive contrast with this first sense, the artificial language in which they have composed the artificial poetry they all like so much. Yet Grierson was in good company when he considered Prakrit to be an "artificial" language. Félix Lacôte noted in 1908 that "the Prakrits, in the strict sense which the grammarians give to this term, have no linguistic reality, or more precisely, they only have an indirect one." 75 To be spoken is to be real. To be written, and especially to be written in accordance with a complex of literary and grammatical conventions, is to be artificial. "From the moment they started writing in Prakrit," Jules Bloch wrote in 1914, "the authors were prisoners of the literary and grammatical tradition." ${ }^{76}$

If a language is "linguistically real" to the extent that it represents the language that people really spoke, then Prakrit clearly poses a problem. Take the example of 
the Kuvalayamālā, a romance by the Jain monk Uddyotana, completed in 779 CE. In a well-known bazaar scene, the narrator quotes small bits of eighteen different languages, some of which sound remarkably similar to the spoken languages of today, and none of which remotely resemble the language of narration throughout the text that Uddyotana himself identifies as Prakrit." It may well be the case that the gap between Prakrit and a "real" spoken language was smaller in the first century than it was in the eighth. But even then, we can only speak in a very vague and speculative way about the "real" language or languages on which Prakrit is based. And this, scholars widely concluded, is a shame. If Prakrit doesn't allow us to make substantive claims about the "real" languages of India, then what is it good for?

At the beginning of his Grammar of the Prakrit Languages (1900), which remains the standard reference work, Richard Pischel observed:

The Prakrit languages are thus "artificial languages" (Kunstsprachen) insofar as they have been significantly modified by poets for literary purposes. But they are not "artificial languages" if it is thereby meant that they are whole-cloth fabrications of the poets. Entirely the same account applies to them as to Sanskrit, which was neither itself the general language of everyday life (allgemeine Umgangssprache) of educated Indians, nor is based on such a language, but certainly harkens back to a dialect spoken by people that was, for reasons of politics or religious history, elevated to the status of a general literary language (Litteratursprache). ${ }^{78}$

I would unpack Pischel's telegraphic comments as follows: people expect Prakrit to be a popular language because it isn't Sanskrit, but it never was such a language; rather, we should think about Prakrit in the same terms in which we think about Sanskrit, namely, as a language that lives in its abundant literature. His comparison makes it clear that artificiality, however we understand it, is not unique to Prakrit, but constitutes a general condition of literary languages in premodern India, and to some extent throughout the rest of the world. It has only become clearer since Pischel's time that whatever tradition we take up-the Vedas of the Brahmans, the Pali canon of the Buddhists, the Ardhamāgadhi canon of the Jains-we are always dealing with a language that has been heavily redacted, revised, and transformed, both intentionally and unintentionally. Pischel's little-appreciated maneuver was to admit the artificiality of Prakrit provisionally, not to discount it as a "philologically worthless" sign of some other language, but to reappraise artificiality itself as an essential feature of the regimes of reading and writing that constitute Indian textuality in general..$^{79}$

We can now distinguish two competing conceptions of language history. August Schleicher, one of the founders of comparative philology, represents the first:

Languages are organisms of nature; they have never been directed by the will of man; they rose, and developed themselves according to definite laws; they grew old, and 
died out. They, too, are subject to that series of phenomena which we embrace under the name of "life." The science of language is consequently a science of nature; its method is generally altogether the same as that of any other natural science. ${ }^{80}$

Schleicher advocates for a natural history of language, which tells the story of how languages change over time according to general laws, and crucially not according to human will. This is the history that philology and linguistics have attempted, and still attempt, to produce. Sanskrit and Prakrit can only ever furnish indirect evidence, important though it may be, in this kind of history. For they do not represent the spontaneously evolving languages of common people, but fixed literary languages. ${ }^{81}$

The second conception is contained in Heinz Kloss's statement that "languages do not just grow and wither like plants." ${ }^{\prime 2}$ Language is not just a natural object, but a cultural object. Language practices are cultural practices. And against those who claim that the uses of language are altogether distinct from the structure of a language itself, this perspective emphasizes that "languages themselves" are not immune to the categorizing, classifying, distinguishing, excluding, regularizing, and standardizing work of culture. Sanskrit and Prakrit can be the subjects of a cultural history of language, since they have been defined and deployed as cultural products all along. This approach does not ask how far the language of a given text can be used as evidence for a "real" language that exists outside of it, but what the real practices were that resulted in the text that we have in front of us. Cultural history complements natural history, but also corrects it. It prevents us from speculating about "the linguistic situation" on the basis of naïve assumptions about the relationship between spoken language and written texts, and it encourages us to account for the linguistic parameters of cultural production: what kinds of languages were Sanskrit and Prakrit, how were they known and represented to the people who actually used them, and why were these languages-and virtually no others-used in literary texts for almost the entirety of the first millennium CE?

\section{INVENTING, FIGURING, KNOWING AND \\ FORGETTING PRAKRIT}

Language of the Snakes offers a biography of Prakrit from the perspective of cultural history. Although one might expect a "biography" of a language to be organized around the biological conceits of birth, life, and death, I have organized this book around the things that people did with Prakrit, the practices that gave it its historical being.

First of all, it had to be invented. The claim that Prakrit was invented, or even the more modest claim that it has a beginning, will seem counterintuitive so long as the prevailing notion of Prakrit is that it arose from the beginningless current 
of popular language. Accordingly, one important scholarly discussion of "Prakrit" begins by surveying attitudes toward language that can be recovered in Vedic texts and grammatical literature, including Patañjali's Mahābhāsya (second century BCE) ${ }^{83}$ By contrast, one of my contentions is that "Prakrit" only began when a set of cultural practices, possessed of a determinate form and commonly recognized by the name "Prakrit," came into existence. I argue that Prakrit emerged as such specifically in the context of the Sātavāhana empire of the Deccan, which lasted roughly from the early first century BCE to the early third century CE. Before this, we can identify all manners of "near-Prakrits"-plenty of Middle Indic dialects, and plenty of instances of the influence of Middle Indic speech on Sanskrit-but nothing that proclaims its linguistic identity as clearly and as consistently as the literature of the Sātavāhana period.

The argument for Prakrit's invention has two parts. Chapter 2 focuses on the inscriptions of the Sātavāhanas, their contemporaries, and successors. I argue that the use of a self-consciously literary style in these inscriptions belongs to a newly aestheticized vision of power that the Sātavāhanas articulated. By taking the latest epigraphic and numismatic evidence into account, I offer a detailed history of inscriptional language practices in the Deccan, which I use to critically revise some commonly accepted ideas about two related phenomena: the appearance of literary prose, and the appearance - and gradual domination - of Sanskrit in literary and political discourse. I argue, first, that a "language of power" formed part of the Sātavāhanas' cultural politics from the dynasty's beginnings, and second, that their conflicts with a competing dynasty, the Kșatrapas, between $50 \mathrm{CE}$ and $150 \mathrm{CE}$ resulted in the contestation and redefinition of this language of power, and in particular, the use-at first experimental—of Sanskrit as such a language, in contrast to the Middle Indic favored by the Sātavāhanas.

Prakrit as we know it, however, belongs to a different domain of the Sātavāhanas' cultural politics. While they promoted one Middle Indic language as the medium of their inscribed "poetry of polity," they promoted another as the medium of courtly literature. This latter language was called "Prakrit." As I argue in chapter 3 , the Sātavāhana court supported and directed a nascent literary culture that would, in turn, be defined by the aesthetics of the court. The works produced under the Sātavāhanas, such as Seven Centuries and Tarangavatī, would become the foundational texts of the Prakrit literary tradition, and of the Indian literary tradition more broadly. If this is not the whole story of the origins of classical Indian literature, it is nonetheless an important and neglected part of it. This chapter examines Seven Centuries in detail as a programmatic statement of the aesthetics of this new literary movement that was centered on the Sātavāhana court. I also argue in this chapter that courtly Prakrit and Jain Prakrit, which are almost always considered separate entities with separate histories, were in fact closely intertwined, as shown by the important contributions of the Jain monk Pālitta, the author of Tarangavatī, to Seven Centuries. 
In chapter 4 I provide a conspectus of some of features of this literature in an attempt to define more clearly what it meant to write in Prakrit, whether it was Hindu kings or Jain monks doing the writing. I listen, first, to its prized aural qualities - its "sweet syllables" - and reflect on the poetic possibilities that its phonology opened up. Then I discuss the metrical forms that were employed in Prakrit literature: I argue that a new style of versification is a sign of the profound influence that Prakrit literature had on a number of textual traditions, since it redefined what it meant to compose in verse. Lastly, I examine some of the ways that Prakrit poems were collected and arranged in anthologies, and how this mode of presentation helped to constitute Prakrit literature as an intertextual field.

During and after its invention, Prakrit had to be figured: it had to be accommodated within a representational structure that would determine its limits and its relations to other languages. Prakrit was a constant and essential component of the threefold, fourfold, and sixfold schemas that mapped the language order of classical India. I examine a range of literary and literary-theoretical texts in chapter 5 to make this case, starting with Kālidāsa's image of the twofold speech of Sarasvatī. Being inscribed into the foundations of a broadly based linguistic imaginary gave Prakrit a classical status that it maintained for its entire subsequent history. It also assigned Prakrit a productively ambiguous status within the classical language order: it was identical to Sanskrit, yet opposite to it; both a language of high literature and, at least notionally, of "the lowest of the low"; unified as a category, yet divided into a seemingly arbitrary number of varieties and subvarieties.

Prakrit then had to be known. It needed to become an object of systematic knowledge, and in this case, of grammar, metrics, and lexicography. These discourses defined Prakrit, and they also provided the conditions for its transregional cultivation. They provided the conceptual tools for comparing Sanskrit and Prakrit, on the one hand integrating Prakrit more fully into a transregional episteme represented by Sanskrit, and on the other resulting in the recognition of "the regional" as a domain resistant to this kind of integration. As a result of these operations, Prakrit had one foot, so to speak, in the Sanskrit cosmopolis and the other in the nebulous domain of the regional. But as such, it provided an ideal model for vernacular literary cultures which sought to theorize themselves as both regional and cosmopolitan. My focus in chapter 6 is on the earlier Prakrit grammars, including fragments of the earliest grammars in Prakrit and Vararuci's Light on Prakrit, as well as some early grammars of Kannada and Telugu.

Finally, Prakrit had to be forgotten, to disappear from the face of the earth and take up residence, according to Mīrzā Khān at least, in the subterranean realm of the serpents. I relate its disappearance to the major reconfiguration of the language order that Prakrit itself had facilitated, the conceptualization and theorization of regional vernaculars: between the vernaculars and Sanskrit, which was given new roles to play, Prakrit was largely squeezed out of most of the genres in which it 
had been written. Although this reconfiguration took place over centuries, it is between the twelfth and thirteenth centuries that its impact on textual production in Prakrit becomes clear. Prakrit texts were abridged, summarized, translated and adapted into Sanskrit, Kannada, Telugu, and Braj Bhāșā. It was kept alive in certain communities, including an ever-shrinking circle of learned Jain monks and the theatrical performers of Kerala, but interest in the language was increasingly antiquarian and scholastic. Authors no longer resorted to Prakrit in order to spin out a tale or recite a verse in literary gatherings. I end with the redetermination of Prakrit as the language of the snakes.

This book thus follows Prakrit over the course of its existence. The goal throughout is to show what that existence consisted in, rather than to document every single thing that it comprised. It is inevitable that there will be absences in such a project. I hope, however, to have established a foundation for a new kind of narrative about Prakrit, and about literary languages within and outside of India. This is not a study of any one text or genre, or a history of Prakrit literature, but an account of Prakrit's position within the language order of India. Some of the materials discussed here will be familiar to every student of Indian literature; some have been completely untouched by scholarship; some are presently available only in manuscript form. This book is intended as a critical reorganization of the way we think of Prakrit, one that shifts the focus away from our own made-to-order definitions and onto the structures that Prakrit was in actual fact embedded in: language schemas, language orders, textual traditions, and literary cultures. It is critical, not just toward particular classifications and historicizations of Prakrit, but toward the classifying and historicizing regimes that predetermine for us what kind of thing language is and thus what kind of thing Prakrit must be. 